\title{
NON-SUBSTANCE ADDICTIONS OF PUPILS OF BASIC AND SECONDARY SCHOOLS (PARTICULAR ATTENTION TO USING OF INFORMATIOM TECHNOLOGY)
}

\author{
Ingrid EMMEROVA
}

Abstract: This article shows risks using information technology by children and youth. The study focus on defect close to pathological addiction. The author presents the warning signals and pay attention to prevention on schools.

Key words: non-substance addictions, pathological addictions, craving, prevention

\section{NELÁTKOVÉ ZÁVISLOSTI U ŽIAKOV ZÁKLADNÝCH A STREDNÝCH ŠKÔL (OSOBITNÝM ZRETELOM NA VYUŽÍVANIE INFORMAČNÝCH TECHNOLÓGII)}

Resumé: Príspevok poukazuje na možné riziká pri použivani informačných technológii det’mi a mládežou v súvislosti so vznikom poruchy, ktorá je blizka patologickej závislosti. Autorka upozorňuje na varovné signály, tiež na nevyhnutnost' prevencie v školskom prostredí.

Kl'účové slová: nelátkové závislosti, patologické závislosti, baženie, prevencia.

Informačné technológie priniesli nespočetné množstvo pozitívneho. Pre deti a mládež žiakov základných a stredných škôl však môžu predstavovat' určité riziko pri ich neadekvátnom používaní, ktoré má blízko k patologickým závislostiam.

V poslednej dobe sme svedkami prudkého vzostupu nielen drogových, ale aj nelátkových závislostí, napr. patologického hráčstva gamblingu, workoholizmu, závislosti na internete a i. Závislost' predstavuje súbor príznakov či symptómov, ktoré vznikajú následkom pôsobenia príslušného podnetu na organizmus alebo psychiku, ale najmä pri jeho absencii.

Medzi iné patologické závislosti, resp. návykové a impulzívne poruchy sa v odbornej literatúre zarad'ujú: patologické hráčstvo, počítače a internet, neadekvátne používanie mobilných telefónov, mobilománia, kultová závislost', workoholizmus, „závislost“" na sexe, patologické nakupovanie, niektoré poruchy príjmu potravy a i. Zameriame sa na neadekvátne a rizikové využívanie informačných technológii det'mi a mládežou.

Craving čiže baženie je relatívne nový termín. Je jedným zo spoločných rysov závislostí na alkohole a iných návykových látkach, ale i patologického hráčstva, workoholizmu, alebo chorobného nakupovania.

K. Kapustová (2007, s. 5) uvádza tieto dôležité informácie o bažení:
- baženie je znakom závislosti,

- baženie sprevádza a bude sprevádzat' každého užívatel’a návykových látok po celý život,

baženie sa časom zmierňuje, prichádza po dlhších časových intervaloch a nie je také naliehavé, ako na začiatku abstinovania,

- baženie môže viest' k racionalizáciám, popieraniu a k tzv. „zdanlivo bezvýznamným rozhodnutiam“,

- baženie oslabuje pamät' a rozhodovacie procesy, spôsobuje, že rozhodnutia závislého sú pod jeho vplyvom iracionálne a unáhlené,

- baženie spolu s podceňovaním závislosti je najčastejším dôvodom, prečo závislí recidivujú a predčasne ukončujú liečbu, baženie výrazne zosilňujú dostupnost' návykovej látky, stretnutie so spúšt’ačmi, nepohoda, rizikové emocionálne stavy, malá schopnost' sebavnímania a sebauvedomovania,

- baženie sa dá prekonat'.

Hazardná hra samozrejme nie je droga, ale problémy $\mathrm{s}$ ňou spojené sú $\mathrm{v}$ našej spoločnosti rozšírené. Hazardná hra vyvoláva poruchu, ktorá sa nazýva patologické hráčstvo gambling, ktorá má v mnohých smeroch blízko k závislosti na alkohole alebo iných drogách. Zarad’uje sa medzi návykové a impulzívne poruchy. Táto porucha spočíva $\mathrm{v}$ častých opakovaných epizódach hazardnej hry, hra 
ovláda život postihnutého na úkor sociálnych, materiálnych, rodinných a pracovných hodnôt. $\mathrm{K}$ najčastejším druhom hazardných hier patria automaty, kasína, kartové hry, stieracie žreby, športové stávky a pod. Pre deti a mládež sú typické automaty a športové stávkovanie, pre starších je to ruleta a hranie v kasínach.

Pre väčšinu mladých l’udí je hranie občasným neškodným trávením vol'ného času, ale existuje riziko, že sa takéto hranie môže zmenit' na problémové a patologické.

Ako uvádza K. Nešpor (2006, s. 16), patologické hráčstvo sa môže rozvinút' u každého, ohrozenejší sú mladí l’udia, hyperaktívne deti s poruchami pozornosti, nezamestnaní a tí, ktorí zlyhali v škole alebo $\mathrm{v}$ učení, muži, l'udia z nebezpečných povolaní (kde človek prichádza do styku s hazardnou hrou alebo sa pohybujú málo kontrolovaným spôsobom volné finančné prostriedky, povolania, kde sa pracuje s vel'kými finančnými prostriedkami v hotovosti apod.), profesionálni hráči, l'udia, ktorí preceňujú význam peňazí a iní.

Medzi varovné znaky patria: čas strávený hraním rastie, časté sú návštevy herní, človek nedokáže s hrou prestat', neodôvodnený optimizmus, zvyšovanie stávok, dlhší čas venovaný hre. Diet'a má neospravedlnené hodiny v škole, zanedbáva školu a svoje povinnosti. Podobne dospelí gambleri absentujú v práci, zanedbávajú pracovné povinnosti, zdravie, rodinu a d'alšie dôležité hodnoty. Gamblerom narastajú dlhy, požičiavajú si stále viac a majú problémy s vyrovnávaním dlžôb. Dopúšt'ajú sa klamstiev, krádeží, podvodov a pod. Prichádzajú depresie a časté sú myšlienky na samovraždu i samovražedné pokusy.

Elektronické médiá napr. televízia, rozhlas, MC a CD, film, internet, môžu byt' využívané na propagovanie a následnú psychickú manipuláciu zo strany siekt a zhubných kultov. Mladí l'udia sú najpotenciálnejšími kandidátmi na členstvo $\mathrm{v}$ deštruktívnych kultoch a sektách. V čase dospievania mnoho mladých l'udí prežíva silnú neistotu, pocit'ujú neporozumenie sveta a neuspokojenie z vlastného života. Adolescenti sú l'ahko ovplyvnitel'ní v krízových momentoch zložitých životných situácií, kedy podl'ahnú bez väčších t'ažkostí psychickej manipulácii zo strany siekt a zhubných kultov (napr. rozchod s dievčat'om alebo chlapcom, rozvod rodičov, smrt' kamaráta alebo člena rodiny, prest'ahovanie sa, zmena školy, prvé opustenie domova a pod.). Následky členstva v deštruktívnom kulte či sekte sú viaceré a závažné. Obmedzovanie spánku či nedostatočná výživa môžu vážne poškodit' zdravie človeka, rovnako závažné sú aj dopady na psychiku. Postihnutý stráca schopnost' realistického úsudku a kritiky. Členstvo môže dokonca v krajných prípadoch viest' $\mathrm{k}$ hromadným samovraždám. Spoločenstvo sa snaží o sociálnu izoláciu mladého človeka, dochádza $\mathrm{k}$ strate väzby a zodpovednosti voči rodine a priatel'om, dochádza $\mathrm{k}$ úplnej strate priatel'ov mimo organizácie.

Workoholizmus sa definuje sa ako závislost' od práce. Pri závislosti na práci možno rozlíšit' tieto rysy (K. Nešpor, 1999, s. 15):

- problémy sidentitou, nadmerné stotožňovanie sa s prácou;

- nepružné myslenie;

- odvykacie t’ažkosti prejavujúce sa nepohodou v situácii, kedy človek z nejakého dôvodu nemôže pracovat';

- charakteristický je progresívny vývoj, ak si človek problém neuvedomí a nezačne s ním niečo robit;

- popieranie problému.

Medzi varovné príznaky závislosti na práci patria únava, bolesti hlavy, nechutenstvo alebo prejedanie sa, bolesti žalúdka a vredy, alergie, telesné vyčerpanie. Zvyšuje sa riziko srdcovocievnych ochorení, objavujú sa tiky, závraty a celkové oslabenie imunitného systému. Častejšie sú úrazy a rôzne nehody. $\mathrm{Na}$ úrovni správania a psychiky sú to výbuchy hnevu, úzkost', nepokoj a poruchy spánku, nadmerná aktivita a neschopnost' odpočívat'. Objavujú sa problémy v rodine, vzájomné odcudzenie a nedostatočná komunikácia. Workoholici majú vel'ké problémy pri práci v skupine.

Dochádza k postupnému poklesu výkonnosti, poklesu energie a niekedy až k nespol'ahlivosti a zlyhávaniu. Už u detí a mládeže preto treba podporovat' pozitívny prístup $\mathrm{k}$ plneniu povinností a adekvátne pracovné návyky.

Počítače a internet sú bežnou súčast'ou nášho života. Zameriame sa na okolnosti, ktoré majú blízko k návykovému chovaniu (K. Nešpor, 2000, s. 35 - 36):

- nadmerné venovanie sa počítaču ako pracovnému prostriedku a nástroju. 
V tomto prípade môže problém súvisiet' s workoholizmom;

- počítačové hry - aj nehazardné počítačové hry majú svoje riziká a ich rizikovost', predovšetkým pre deti, je evidentná. Patrí sem zanedbávanie školy a školských povinností, zaostávanie v sociálnom vývoji, riziká pre zdravý vývoj pohybového systému, prvok násilia a riskovania sa nachádza $\mathrm{v}$ mnohých hrách;

- internet ako prostriedok $\mathrm{k}$ hazardnej hre tu je jasný prechod $\mathrm{k}$ patologickému hráčstvu a súvisiacim problémom;

- internet a pornografia, práve pornografické stránky sú na internete najnavštevovanejšie; - internetové diskusné skupiny - „,chat" nadmerná účast' na týchto diskusiách, ked' postihnutý človek často zanedbáva svoje reálne vzt’ahy kvôli povrchným kontaktom na internete.

Počítačové hry - aj nehazardné počítačové hry majú svoje riziká a ich rizikovost', predovšetkým pre deti, je evidentná. Patrí sem zaostávanie v sociálnom vývoji, riziká pre zdravý vývoj pohybového systému, prvok násilia a riskovania sa nachádza $\mathrm{v}$ mnohých hrách.

Internet ako prostriedok $\mathrm{k}$ hazardnej hre tu je jasný prechod k patologickému hráčstvu a súvisiacim problémom. Ďalším rizikom sú stránky, ktoré svojím obsahom nie sú vhodné pre deti.

Popri nesporných výhodách intenretu, vo vzt'ahu k žiakom základných a stredných škôl je potrebné poukázat' aj na niektoré riziká. Virtuálny svet internetu ponúka prostredie bez zábran a subjektívny pocit anonymity. Je to priestor, kde je možné klamat' či uvádzat' polopravdy, pre pubescentov a adolescentov môže byt' internet zdrojom nevhodných až nebezpečných informácií.

Internet prispieva aj $\mathrm{k}$ rozširovaniu prostitúcie, ktorý slúži ako ponukový katalóg spôsobu, formy a rozsahu prostitúcie. $\mathrm{Na}$ internete môžeme nájst' množstvo odkazov na erotické stránky vzt’ahujúce sa na ponúkanie prostitúcie. Dovol'ujem si poznamenat', že v poslednom období sme svedkami nárastu prípadov detskej prostitúcie, čo súvisí s vel'kým nárastom odhalenia prípadov detskej pornografie na území našich susedných štátov. K rozširovaniu foto a videodokumentácie detskej pornografie slúži najmä internet.
Internet, počítačové hry, mobilné telefonovanie, posielanie sms správ môžu byt' potenciálne zdroje prežívania príjemných stavov a „vzt'ah knim môže u predisponovaných osôb, ktoré si neuvedomujú hroziace riziko, nadobudnút' charakter psychickej poruchy úzko súvisiacej so závislost'ami od návykových látok.“ (L. Nábělek; In: 2003, s. 92)

$\mathrm{Na}$ zdravotné riziká počítačových hier poukazujú i K. Nešpor a L. Csémy (2007, s. 1 2). Uvádzajú ich negatívny dopad na pohybový systém, vznik obezity a nesprávnych stravovacích návykov, zrak, zvyšujúca sa tendencia riskovat' a častejšie úrazy, „vyhasína strach z násilia“, zhoršené vzt’ahy, sociálne zručnosti a zhoršený školský prospech.

Základné a stredné školy kladú pri prevencii sociálnopatologických javov dôraz predovšetkým na prevenciu drogových závislostí. Pre realizovanie primárnej prevencie je nevyhnutné si uvedomit', že deti a mládež nie sú ohrozované iba látkovými závislost’ami, ale aj d'alšími patologickými závislost'ami. Fyzické, psychické i sociálne zdravie detí a mládeže ohrozujú automaty, počítače a internet, neadekvátne používanie mobilných telefónov.

Prínosným je aj realizovanie Komunitárneho programu Európskej únie „Zodpovedne.sk“, ktorého ciel'om je zvýšit' povedomie o bezpečnom a zodpovednom užívaní internetu, šírit' osvetu a prispiet' tiež k prevencii internetovej kriminality. V spolupráci s realizátormi projektu Ministerstvo vnútra pripravilo program pre deti a mládež Cookie.sk, ktorého ciel'om je informovat' ich o nástrahách internetu a internetovej kriminalite.

Pri prevencii kultovej závislosti je nutné zvýšit informovanost' mladých l'udí o technikách náboru, ako aj o nebezpečenstve členstva $\mathrm{v}$ deštrukčných sektách a kultoch. Efektívne sú diskusie na túto tému v školách, ale aj v médiách - televízii, rozhlase či tlači.

Ťažisko prevencie neadekvátneho používania a rizík internetu, počítačových hier, mobilného telefonovania, posielania sms správ spočíva v nasledovných krokoch: včas rozpoznat' varovné známky (zhoršenie prospechu, únava, strata záujmov a kvalitných priatel'ov), stanovit' jasné pravidlá práce s počítačom i pravidlá používania telefónu, umiestnit' počítač na také miesto, aby dospelí videli a zabránili nevhodnému používaniu (pornografia, násilné hry). Nevyhnutné je 
poskytnút' det'om možnosti aktívneho trávenia vol'ného času.

Pri prevenčných aktivitách na základných a stredných školách je dôležité nezabúdat' popri prevencii drogových závislostí na prevenciu iných patologických závislostí. Prevenciu je potrebné začlenit' do rámca výchovy k zdravému spôsobu života.

Včasná a efektívna prevencia je nevyhnutná. Spolupráca škôl s odborníkmi v oblasti prevencie je nevyhnutná. Škola musí aktívne spolupracovat' s mimo-školskými inštitúciami a organizáciami.

V súvislosti s prevenciou patologického hráčstva u detí a mládeže možno pozitívne hodnotit' aktivity Policajného zboru SR, ktorý vykonáva kontrolu herní s hracími automatmi. Táto činnost' je prínosná aj pri predchádzaní záškoláctva, užívania alkoholických nápojov a iných návykových látok.

Pri prevencii drogových závislostí i nelátkových závislostí je ciel’om zabránit' experimentovaniu alebo aspoň oddialit' experimenty s drogami či rizikovými činnost'ami u detí a mládeže. Možno súhlasit' s D. Novákovou $(2008$, s. 7) podl'a ktorej je vhodné, aby „každý preventívny program zameraný na závislosti obsahoval prevenciu legálnych i nelegálnych drog a zároveň prevenciu nelátkových závislostí“. Pri prevencii je nevyhnutné začínat' preventívne aktivity $2-$ 3 roky pred predpokladaným užitím drogy či rizikovej činnosti. Preto je potrebné adekvátnym a veku primeraným spôsobom realizovat' primárnu prevenciu v predškolských zariadeniach a na prvom stupni základných škôl.

Primárna prevencia je nesmierne dôležitá, predovšetkým vo vekovej kategórií žiakov prvého stupňa základnej školy, ale aj u predškolákov. Nevyhnutná je $v$ tejto oblasti spolupráca rodiny a školy. Učitel' by mal rodičov informovat' o možnostiach poradenstva, o odbornej pomoci či navrhnút' spoluprácu s odborníkmi v prípade výskytu problémov. Už pri spozorovaní menších problémov by mal učitel' kontaktovat' rodičov a zistit', či je $\mathrm{v}$ rodine všetko v poriadku. Napriek všetkým opatreniam v škole nad'alej platí, že najlepšou prevenciou je dobrá rodina!

Okrem primárnej prevencie, na ktorú kladú dôraz aj strategické dokumenty SR Národný program boja proti drogám a Stratégia prevencie kriminality v Slovenskej republike je potrebné realizovat' aj sekundárnu prevenciu. Táto sa zameriava na rizikových jedincov či skupiny. Jej ciel'om je vrátit' jedinca do pôvodného stavu a systematicky ho kontrolovat' kvôli riziku opätovného zlyhania. Ďalej je nutné, aby boli učitelia informovaní a pripravení reagovat' pri výskyte rizikového správania, ako aj v oblasti prevencie.

\section{Literatúra:}

(1) NÁBĚLEK, L.: In: JANIAKOVÁ, D.: Tak už dost'! Východiská zo závislostí. Bratislava : Kontakt, 2003. 220 s. ISBN 80-96895-0-7

(2) KAPUSTOVÁ, K.: Silná túžba ako diagnostické kritérium. In: Čistý den̆. 2007, č. 2, s. $4-5$.

(3) NEŠPOR, K. - CSÉMY, L.: Zdravotni rizika počitačových her a videoher. 2007, 6 s. In: www.plbhonice.cz

(4) NEŠPOR, K.: Návykové chování a závislost. Praha : Portál, 2000. 150 s. ISBN 80-7178432-X

(5) NEŠPOR, K.: Už jsem prohrál dost. Praha : Sportpropag, 2006. 72 s. In: www.plbhonice.cz/ nespor/addictz.html

(6) NEŠPOR, K.: Závislost na práci. Praha : Grada Publishing, 1999. 144 s. ISBN 807169-764-8

(7) NOVÁKOVÁ, D.: Prevencia nelátkových závislostí v materských školách a na prvom stupni základných škôl v programe Zdravý spôsob života a prevencia závislostí. In: Sociálna prevencia. 2008, č. 1, s. 7.

Doc. PhDr. Ingrid Emmerová, PhD.

Pedagogická fakulta UMB

Katedra pedagogiky

Ružová 13

97411 Banská Bystrica

Slovenská republika

E-mail: iemmerova@pdf.umb.sk 